\title{
Palaeontological surveys in Central Sumatra and Bangka
}

\author{
Julien Louys ${ }^{1}$, Yahdi Zaim², Yan Rizal2, Gilbert J. Price, Aswan², Mika Rizki Puspaningrum², \\ Holly Smith ${ }^{1}$, and Agus Trihascaryo ${ }^{2}$ \\ ${ }^{1}$ Australian Research Centre for Human Evolution, Griffith University, Queensland, Australia \\ ${ }^{2}$ Geology Study Program, Institut Teknologi Bandung, Jawa Barat 40132, Indonesia \\ ${ }^{3}$ School of Earth and Environmental Sciences, The University of Queensland, St Lucia, \\ Queensland 4072, Australia
}

\begin{abstract}
We report on results from surveys undertaken in Sumatra during 2018 and 2019. The surveys had three objectives: (1) to examine, sample, and record the extensive Quaternary fossil deposits from caves in West Sumatra; (2) determine the potential for fluvial deposits in Riau and Jambi provinces; and (3) relocate the fossil proboscidean remains reported from Bangka Island. Our surveys produced several significant results. We mapped three important Padang Highland caves, Ngalau Lida Ajer, Ngalau Sampit, and Ngalau Gupin, locating and sampling the main fossil deposits in each, as well as recording additional caves in the region. Our surveys of the fluvial systems in central-west Sumatra did not reveal any vertebrate Pleistocene deposits but did yield Mio-Pliocene trace fossils. Finally, we relocated elephant fossils from Bangka, but no in situ vertebrate remains could be found. These finds add important new data to the geological history of Sumatra.
\end{abstract}

Keywords: proboscidean, Quaternary, Bangka Island, Central Sumatra

\footnotetext{
Copyright (C2021. FOSI. All rights reserved.

A Special Publication of abstracts and extended abstracts from the conference in honor of the retirement of Prof. Yahdi Zaim, IPU (22-23 March 2021).

DOI: $10.51835 /$ bsed.2021.47.3.358
} 


\section{INTRODUCTION}

The island of Sumatra forms part of the continental landmass of Sundaland. It is the sixth largest island, and is distinctly asymmetric, with the western part of the island characterized by extensive mountain building from a Cenozoic volcanic arc system, and the eastern part consisting of a sedimentary basin with young folding and more recent alluvial plain deposits (Hutchinson, 1989; Verstappen, 1973). Off the east coast of Sumatra lies the islands of Belitung and Bangka, and the Lingga and Riau archipelagos, comprised of peneplains, residuals hills, and a Quaternary cover of mainly fine sands (Verstappen, 1973).

Across these landforms, we undertook a palaeontological survey program aimed at locating significant Quaternary fossil deposits. The rationale behind this transect was straightforward. Important palaeontological deposits had been recorded from the Padang Highland caves by Dubois (Dubois, 1891), and Paleogene vertebrates and trace fossils from the Ombilin Basin had been described (e.g. Zaim et al., 2014; Zonneveld et al., 2011). We had been able to relocate several of Dubois's Padang Highland caves as well as discovering new fossil deposits in the region (Louys et al., 2017). However, the extent of these deposits and the cave systems they were found in required more extensive recording.

The Quaternary vertebrates recovered from the Padang Highland caves were representative of rainforests. However, during several important periods of the Quaternary, notably the middle Pleistocene, extensive savannah ecosystems dominated central Sundaland (Louys and Roberts, 2020). The full extent of these savannahs is still poorly known, and whether they extended into Sumatra can't be established based on available data. The peneplains of eastern Sumatra hold promise for the recovery of fossils that would inform on the presence of rainforests or savannahs in the Pleistocene. These are characterized by extensive alluvial plains and swamps dissected by well-developed river terraces (Verstappen, 1973). Finally, survey of the Nibung and Mentok region was undertaken to relocate vertebrate fossils that had been reported from the island by Martin (1884).

\section{METHODOLOGY}

Terrestrial surveys proceeded on foot with GPS units for locality recording. Underground surveys employed linelevels and laser range finders for difficult to access chambers. This allowed us to map geomorphology and cave topography through each system. Cemented deposits were extracted with geological hammers, ensuring that orientation and position of blocks relative to speleothems are recorded. All soft sediment samples were wet sieved through sieves to recover microfauna, with initial sorting on site. 


\section{RESULTS}

\section{$\underline{\text { Padang Highlands }}$}

Lida Ajer was surveyed between 23rd and $25^{\text {th }}$ June 2018. The sinkhole at the rear of the cave was fully explored and mapped. An approximately $1 \times 1 \mathrm{x}$ $1.6 \mathrm{~m}$ pit was encountered just past the southwest arm of the sinkhole passage, and its stratigraphy logged. Teeth were extracted from the walls and floors of the sinkhole passages, and at along various points of the sinkhole for U-series and ESR dating. One stalagmite was recovered broken from the sinkhole and collected. The four discrete breccia sites were identified along the northern wall of the main chamber and intact breccia block samples were extracted systematically from each of these. Dating results from these samples will be reported elsewhere (Louys et al., in prep).

Ngalau Sampit was examined on June 27,2018 . It was fully explored, but only partially mapped, with focus on the breccia-bearing passages of the cave. The exploration encountered and largely penetrated several flooded passages and found two additional entrances to the cave. The main chamber of Ngalau Sampit divides into two breccia bearing passages, bearing east and west in the northernmost extent of the main chamber. Breccia blocks and teeth were extracted for dating and confirm the deposition dates to MIS 5 (Duval et al., in prep).

Ngalau Gupin was mapped and explored between $29^{\text {th }}$ June and $2^{\text {nd }}$ July 2018. Teeth were extracted from the main lithified units, as well as the unconsolidated muds situated below the breccia. Teeth were extracted for dating, and taphonomic and palaeoecological analyses. Remains from the unlithified deposits were sieved through $0.5 \mathrm{~mm}$ mesh at the river to recover small remains. Two discrete breccia sites were present in Ngalau Gupin. The first exposures are present on the cave floor, eastern wall, and western wall of a U-shaped curved passage of which both entrances connect to the southernmost extent of the main chamber of Ngalau Gupin. The breccia deposit of the eastern wall extends only around one meter into the passage entrance; the western wall extends around to the inner southfacing wall. The second breccia site is evident on the cave floor directly outside of the curved passage which dips steeply down as a south-facing wall of mud deposits below the two entrances. The breccia is only faunalbearing in the westernmost wall of the western passage of the first breccia site and the topmost layer of the southfacing wall of the second breccia site. Results on the taxonomic, taphonomic, and chronological studies is forthcoming (Smith et al., under review).

In addition to the work in these caves, three more caves in the Padang Highlands were explored for potential new deposits. Gua Atas and Gua Bawah are situated on the same uplifted limestone; however, are topographically distinct. Gua Atas, the higher of the two, is a moderately-sized cave full of graffiti. Approximately 200 $\mathrm{m}$ below is Gua Bawah, a much larger system with several openings. One 
Macaca incisor was recovered from the surface, and a mollusk in breccia. There are areas near one of the entrances which appear to have a large living space with deep sediment, however, this was not explored further. Gua Jianjin, near Sibarambang, has a relatively small entrance, with a steeply inclined initial passage that opens into several large, interconnected chambers, and an active streambed at the base. Although we identify several separate breccia formations, none of these host any vertebrates. The breccias consist of pebble to cobble-sized clasts, well rounded and poorly sorted.

\section{Logas Hilir River}

Most of our attention was focused on Logas Hilir River. We encountered a series of river gravels and conglomerates, likely of late
Pleistocene and Holocene age. No vertebrates were found. The only buried organic matter observed were macro botanical and wood deposits, most likely Holocene in age, occurring between the river gravels (Figure 1).

\section{Taluk to Rengat}

Examination of outcrops between Taluk and Rengat produced no vertebrates. However, we recorded several ichnological sites in the region (Figure 2). These consist of fine silts and sandy beds with abundant rhizoliths preserved. These were recovered from areas corresponding to the Muaraenim Formation, and thus are likely to be middle to late Miocene in age. The rhizoliths are relatively large in diameter, with vertical and diagonal orientations observed when

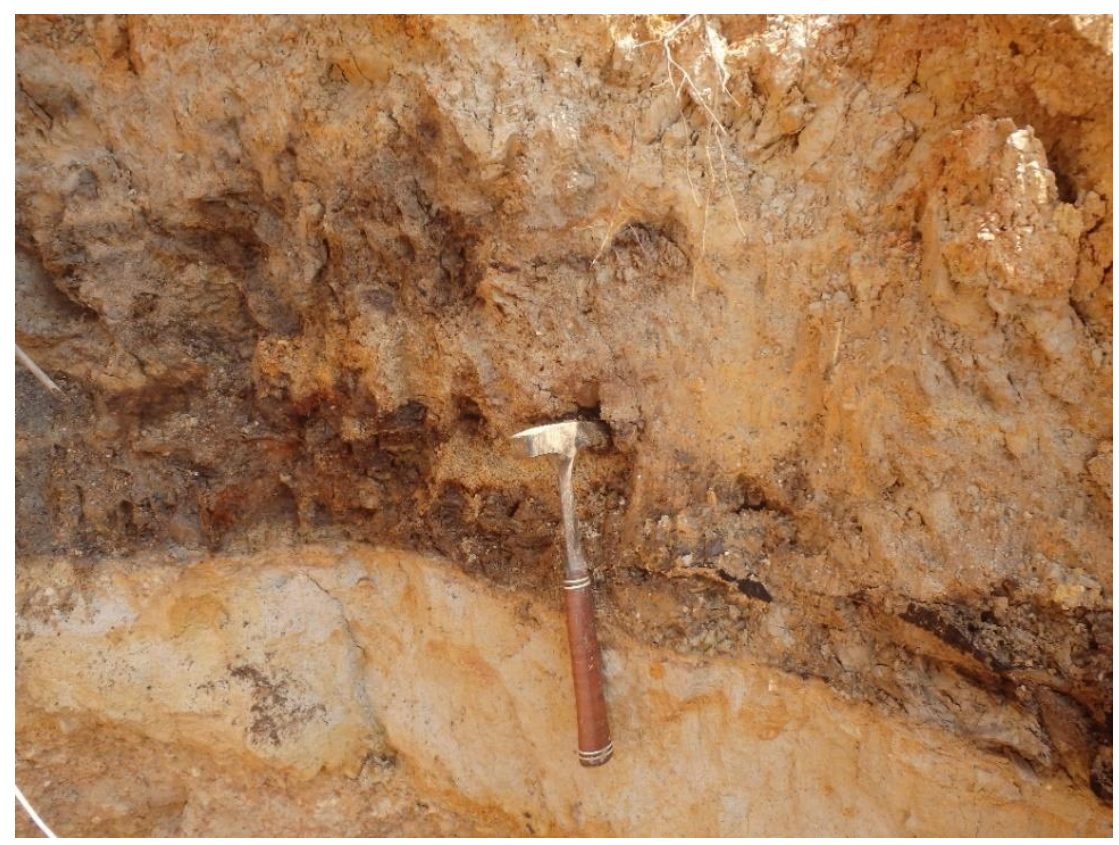

Figure 1. Organic rich layer in the Logas Hilir River terrace deposits, consisting of macro botanical and large wood fragments. 


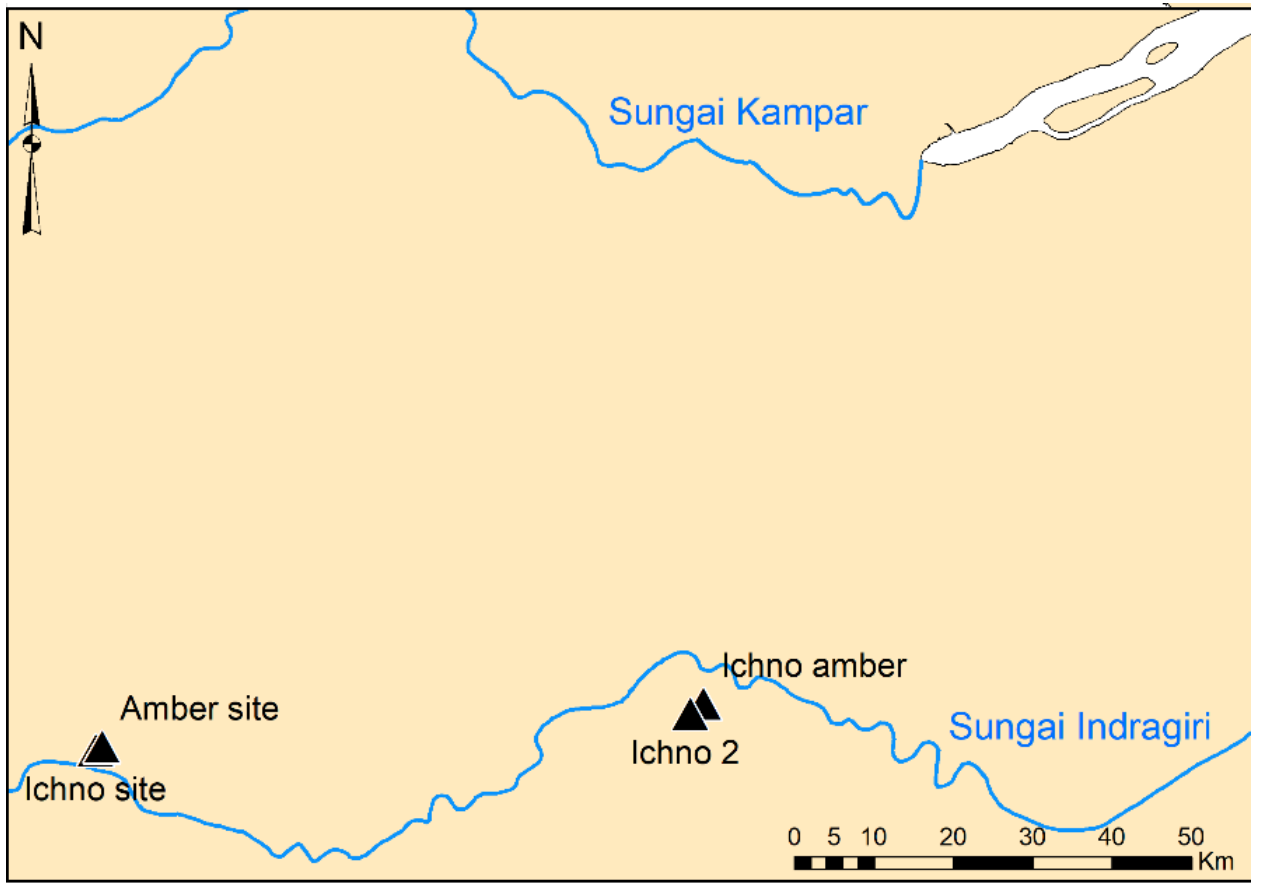

Figure 2. Location of sites producing rhizoliths (Ichno sites) and copal deposits (Amber sites) along Sungai Indragiri (map courtesy of Shimona Kealy).

preserved in situ. This indicates that the roots formed in the vadose zone, and implies the presence of irregular, intermittent water supply such as a channel-bar or overbank fluvial deposits (Mount and Cohen, 1984). Iron-staining of the rhizoliths indicates the presence of monsoonal tropical soils and paleosols (Retallack, 1991). While the remains do not indicate where the top of the land surface was located, it does suggest stable land surface was present during deposition, probably a well-drained upland setting (Mount and Cohen, 1984). Overall, the rhizolith abundance, distribution and size suggests a moderate to high density of wooded vegetation. No vertebrate terrestrial remains were found.

In several locations, including one of the rhizolith sites, we collected surface copal. These are well-rounded and have perhaps undergone some transportation prior to deposition. Their recovery is consistent with the presence of trees in the area. Thus, the area between Taluk and Rengat is reconstructed as being riparian tropical woodland to forest. These observations are consistent with the interpretation of the formation as representing a humid tropical deltaic system (Boyd and Peacock, 1987).

Near Kuantan, we also explore an abandoned coal mine site Bukit Asam Pranap. This mine preserved the MioPliocene sequence of the region. Examination of some of the laminated coal deposits reveals several botanicals as well as small fragmentary fish remains. 


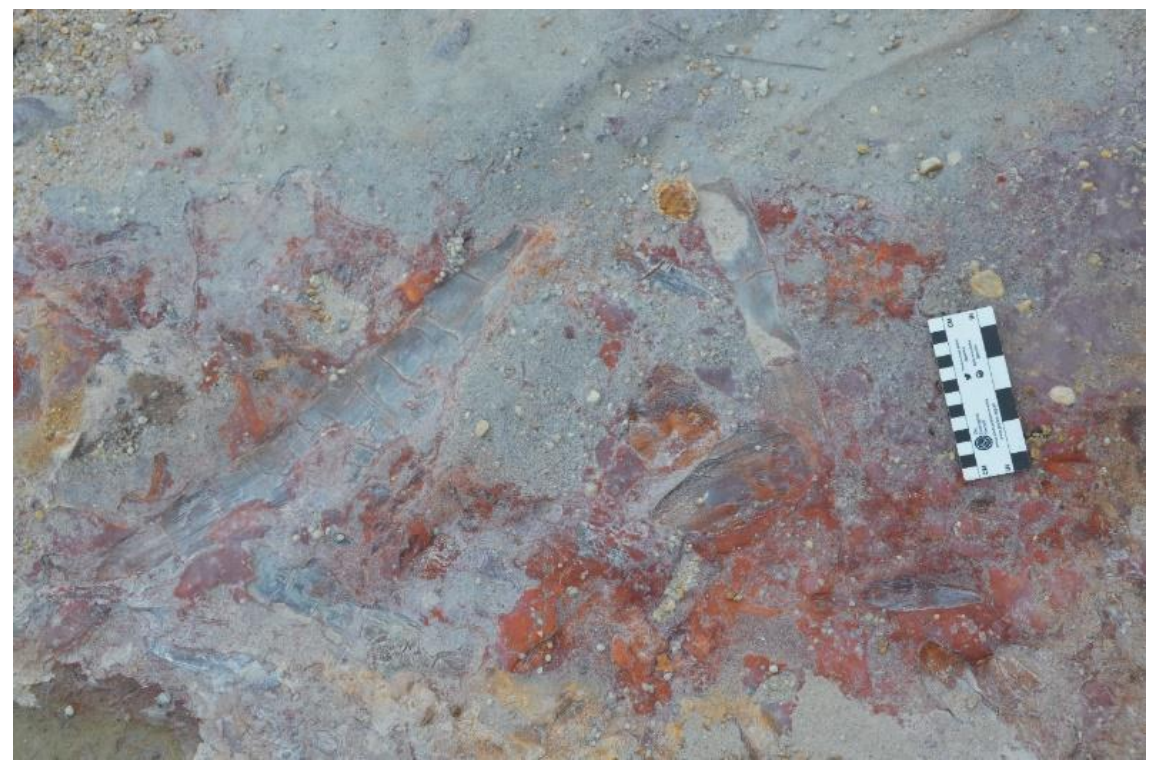

Figure 3. Fossil wood stem fragments, Mentok.

\section{Bangka Island}

Survey of this island took place in June 2019, and unfortunately most of the original Pleistocene outcrops occurring on the island have been destroyed by mining activities, such that only a few intact sections were observed. Nevertheless, we were able to locate ex situ Elephas maximum fossils, having been found by local miners close to where they were reported from in Nibung. In addition, fossil plant impressions and rhizoliths were observed in the Mentok area (Figure 3), although the former could only be identified to decorticated wood (stem) fragments (Andrew Rozefelds, pers. comm. 2019). The elephant fossils have been sampled for dating and isotopes, and results are currently pending.

\section{CONCLUSION}

Our preliminary survey has highlighted the rich palaeontological record of the Padang Highlands and revealed the potential for important palaeoenvironmental sites in the sedimentary basin and alluvial plains of eastern Sumatra and Bangka. Quaternary vertebrate fossils, however, remain elusive. Their discovery will likely be best facilitated by reports from local people, although it is recommended that further exploration and survey take place, particularly in the eastern foothills of the Barisan Mountains.

\section{ACKNOWLEDGEMENTS}

Funding for this study was provided through an ARC Future Fellowship grant to Julien Louys (FT 160100450). We thank Shimona Kealy for producing the map for Figure 2. 


\section{REFERENCES}

Boyd, J.D. and Peacock, S.G., 1986. Sedimentological analysis of a Miocene deltaic systems: Air Benakat and Muaraenim Formations, Central Merangin Block, South Sumatra. Indonesian Petroleum Association 15th Annual Convention Proceedings, 1, 245-258.

Dubois, E., 1891. Voorloopig bericht omtrent het onderzoek naar de Pleistocene en Tertiaire VertebratenFauna van Sumatra en Java, gedurende het jaar 1890. Natuurk. Tijdschr. Ned. Ind., 51, 93-100.

Hutchison, C. S., 1989. Geological evolution of South-east Asia. Oxford Monographs on Geology and Geophysics, 13, 1-368.

Louys, J., Kealy, S., O'Connor, S., Price, G.J., Hawkins, S., Aplin, K., Rizal, Y., Zaim, J., Mahirta, Tanudirjo, D.A., Santoso, W.D., Hidayah, A.R., Trihascaryo, A., Wood, R., Bevitt, J. and Clark, T., 2017. Differential preservation of vertebrates in Southeast Asian caves. Int. J. Speleol., 46, 379-408.

Louys, J. and Roberts, P., 2020. Environmental drivers of megafauna and hominin extinction in Southeast Asia. Nature, 586, 402-406.

Martin, K., 1884. Ueberreste vorweltlicher Proboscidier von Java und Banka. Sammlungen des Geologischen Reichs-Museums in Leiden. Serie 1, Beiträge zur Geologie Ost-Asiens und Australiens, 4, 1-24.
Mount, J.F. and Cohen, A.S., 1984. Petrology and geochemistry of rhizoliths from Plio-Pleistocene fluvial and marginal lacustrine deposits, east Lake Turkana, Kenya. J. Sed. Petrol., 54, 263-275.

Retallack, G.J., 1991. Miocene Paleosols and Ape Habitats of Pakistan and Kenya (No. 19). New York: Oxford University Press; Oxford [England]: Clarendon Press.

Verstappen, H.T., 1973. A Geomorphological Reconnaissance of Sumatra and Adjacent Islands (Indonesia) (Vol. 1). Wolters-Noordhoff.

Zaim, Y., Gunnell, G.F., Ciochon, R.L., Rizal, Y., Aswan and O'Shea, N.O., 2014. Paleogene Vertebrates from Tanahsirah, Talawi-Ombilin Basin, West Sumatra, Indonesia: a preliminary field result. Bull. Geol., 41, 175-184.

Zonneveld, J.P., Zaim, Y., Rizal, Y., Ciochon, R.L., Bettis III, E.A., Aswan and Gunnell, G.F., 2011. Oligocene shorebird footprints, Kandi, Ombilin Basin, Sumatra. Ichnos, 18(4), 221227. 